Volume 18 Number 2 December 2018. p.481-500

https://doi.org/10.30603/au.v18i2.660

\title{
Kontruksi Pemikiran Keagamaan tentang Nilai-Nilai Nasionalisme Pada Penceramah di Masjid Agung Surakarta dan Sukoharjo
}

\author{
Moh. Abdul Kholiq Hasan, Kamila Adnani, Moh. Mahbub \\ IAIN Surakarta
}

\begin{abstract}
This is a field research using a qualitative descriptive approach. This research aims at understanding the construction of religious thought about the values of nationalism and nationalism insights by preachers at the Great Mosque of Surakarta and Sukoharjo. The results of the study indicate that the constructs of religious thought by the preachers can be divided into two types. First, fundamentalist preachers; Nationalist thought which always makes religious texts the only foothold, too idealized and normative footing, like HTI and Salafi preachers. Second, moderate preachers; Nationalist thought which do not make religious texts the only basis but also saw reality and maqashid sharia, flexible and realistic, like Tarbiyah-PKS and NU preachers. Nationalism insights cover five main points of nationalism values, namely the Pancasila, the love of the homeland and the Republic of Indonesia, tolerance and diversity, democracy and deliberation, respect for the red and white flag and the national anthem. In general the preachers accept and support those. Only HTI and Salafi do not accept democracy which is, on their mind, contrary to Islam. HTI accepts the concept of the NKRI but under the auspices of the Caliphate.
\end{abstract}

\begin{abstract}
Abstrak
Jenis penelitian ini adalah penelitian lapangan menggunakan pendekatan deskriptif kualitatif. Penelitian ini bertujuan untuk memahami konstruksi pemikiran keagamaan tentang nilai-nilai nasionalisme dan wawasan nasionalisme yang terdapat pada para penceramah di masjid Agung Surakarta dan Sukoharjo. Hasil penelitian penunjukkan bahwa konstruksi pemikiran keagamaan para penceramah dapat dibagi dua tipe. Pertama, penceramah fundamentalis; pemikiran nasionalis yang selalu menjadikan teks-teks agama sebagai pijakan satu-satunya, terlalu idialistik dan normatif. Seperti penceramah HTI dan Salafi. Kedua, penceramah moderat; pemikiran nasionalis yang tidak menjadikan teks-teks agama sebagai pijakan satu-satunya tetapi juga melihat rialita dan maqâsid syarîah, fleksibel dan realistik. Seperti penceramah Tarbiyah-PKS dan NU. Sedang wawasan nasionalisme telah mencakup lima hal pokok nilai-nilai nasionalisme. Yaitu Pancasila, cinta tanah air dan NKRI, toleransi dan keragaman, demokrasi dan musyawarah, hormat bendera merah putih serta lagu kebangsaan. Secara umum para penceramah menerima dan mendukungnya. Kecuali terkait dengan demokrasi yang menurut penceramah HTI dan salafi bertentangan dengan Islam. HTI menerima konsep NKRI tetapi dibawah naungan khilâfah.
\end{abstract}

\section{Kata Kunci: Konstruksi Pemikiran Keagamaan, Nasionalisme, Penceramah, Masjid Agung.}

Author correspondence

Email: hasanuniversitas@gmail.com

Available online at http://journal.iaingorontalo.ac.id/index.php/au/index 


\section{A. Pendahuluan}

Isu nasionalisme akhir-akhir ini mencuat kembali ke permukaan. Berbagai gesekan antar kepentingan dan kelompok masyarakat semakin terasa. Terutama pasca pilpres 2014 dan pilkada Jakarta yang menyedot perhatian nasional bahkan internasional ${ }^{1}$. Ditambah lagi suhu perpolitikan nasional menjelang Pilkada 2018 dan Pilpres 2019 yang secara umum semakin memanas. ${ }^{2}$ Untuk itu banyak pihak telah mengingatkan agar masyarakat Indonesia jangan terjebak pada kondisi yang dapat merusak persatuan dan kesatuan bangsa. Dan pentingnya kembali penguatan nilai-nilai nasionalisme dalam diri masyarakat. ${ }^{3}$

Masjid sebagai pusat aktivitas da'wah dan kebudayaan umat Islam, memiliki peran yang bengitu luas dan sentral bagi kehidupan masyarakat muslim. Termasuk dalam penanaman dan pembinaan nilai-nilai nasionalisme. Sekaligus menjadi benteng dari penyebaran paham-paham anti NKRI. ${ }^{4}$ Nilai-nilai nasionalisme ini dapat disampaikan lewat ceramah-ceramah keagamaan yang diselenggaran oleh pengurus masjid.

Kajian Islam yang dilakukan oleh para penceramah dimasjid-masjid, terutama di masjid Agung sangat menarik untuk diteliti. Disamping terkait dengan lokasi dan perannya yang sangat strategis dalam pembentukan masyarakat, juga terkait dengan pemahaman teks-teks agama. Seperti teks al-Qur'an yang mengandung berbagai interpretasi, yang dapat disalah gunakan oleh oknum yang tidak bertanggung jawab. ${ }^{5}$ Karena dalam memahami teks agama tersebut menyalahi syarat-syarat dan rambu-rambu yang ditentukan ulama yang

\footnotetext{
1http://internasional.kompas.com/read/2017/04/20/07000051/kekalahan.ahok.dan. kemenangan. anies. dalam.sorotan.media.asing; diakses pada tanggal 09 Nopember 2017.

2Lihat:http://nasional.kontan.co.id/news/temuan-pemerintah-suhu-politik-mendidih-di-2018; diakses pada tanggal 09 Nopember 2017.

3Lihat:http://www.tribunnews.com/nasional/2017/09/11/jokowi-jangan-gampang-dikipaskipasi-jangan-sampai-diadu-domba; diakses pada tanggal 09 Nopember 2017.

${ }^{4}$ Lihat:http://news.metrotvnews.com/read/2017/05/19/702572/masjid-harus-jadi-bentengpertahanan-nkri; diakses pada 05 Oktober 2017.

5 Moh. Abdul Kholiq Hasan, "Penafsiran Alquran dan ikhtilaf Ulama (Kaidah dan Etika Memahami Perbedaan Penafsiran)”, dalam El-Hayah-Jurnal Ilmu-Ilmu Keislaman, Vol. 1 No. 1, (2012):14.
} 
Kontruksi Pemikiran Keagamaan tentang Nilai-Nilai Nasionalisme Pada Penceramah di Masjid Agung Surakarta dan Sukoharjo

kompeten. ${ }^{6}$ Sehingga al-Qur'an sebagai kitab petunjuk tidak difungsikan sebagaimana mestinya. ${ }^{7}$

Masjid Agung Surakarta dan Sukoharjo, adalah dua masjid Agung yang terletak di propinsi Jawa Tengah. Keduanya memiliki peran yang sangat strategis dalam pembinaan agama masyarakat. Keduanya berdampingan secara geografis, dan memiliki kemiripan corak keberagamaan. Keduanya juga sering dikaitkan dengan pemberitaan radikalisme dan teroris serta munculnya kelompok Islam radikal seperti Jamaah Islamiyah (JI), Hizbut Tahrir Indonesia (HTI), Jamaah Anshor Tauhid (JAT), ISIS dan sebagainya. ${ }^{8}$ Fenomena tersebut menarik untuk dikaji, terlibih adanya indikasi bahwa kelompok-kelompok tersebut telah melakukan infiltrasi dalam kajian-kajian keislaman yang dilaksanakan di masjidmasjid. ${ }^{9}$

Berdasarkan latar belakang masalah di atas, rumusan penelitian ini adalah bagaimana konstruksi pemikiran keagamaan para penceramah tentang nasionalisme? dan wawasan nasionalisme apa yang dimiliki para penceramah di Masjid Agung kota Surakarta dan kabupaten Sukoharjo?

Terkait dengan tema penelitian, sebelumnya terdapat tulisan dalam Jurnal "Analisa" Vol. 21 No. 02 Desember 2014. dengan judul "Muatan Nilai-Nilai Multikultural dan Anti-Multikultural dari Mimbar Masjid di Kota Solo", oleh Zakiyuddin Baidhawy. Hasil penelitian menyimpulkan bahwa pengkhotbah belum banyak membahas keragaman di berbagai masjid dan majelis taklim.

Artikel berikutnya ditulis oleh Muh. Khamdan, dengan judul "Pengembangan Nasionalisme Keagamaan Sebagai Strategi Penanganan Potensi Radikalisme Islam Transnasional" dalam Jurnal ADDIN, Vol. 10, No. 1, Februari

\footnotetext{
${ }^{6}$ Reflita, "Kontroversi Hermeneutika Sebagai Manhaj Tafsir (Menimbang Penggunaan Hermeneutika dalam Penafsiran al-Qur'an)", dalam Jurnal Ushuluddin, Vol. 24 No.2, (2016): 145.

7 Moh. Abdul Kholiq Hasan, "Metode salafush shalih dalam berinteraksi dengan Al-Quran", dalam Jurnal Al-'ARAF, Vol. XII, no. 2 Juli (2015): 52.

${ }^{8}$ Berikut beberapa berita terkait radikalisme dan terorisme di Surakarta dan Sukoharjo diantaranya;http://solo.tribunnews.com/2018/09/10/kota-solo-tergolong-zona-merahpenyebaran-radikalisme-dan-terorime-diindonesiac,http://jateng.tribunnews.com/2017/12/06/najahan-sebut-paham-radikalisme-takhanya-di-solo-raya; diakses pada 05 Oktober 2017.

${ }^{9}$ https://www.kompasiana.com/al-makassary/benih-benih-islam-radikal-di-masjid, https://www. bbc.com/indonesia/berita indonesia/2016/02/160224_indonesia_masjid_isis; diakses pada: 02 Nopember 2017.
} 
2016. Hasil kajian menunjukkan bahwa berbasiskan kepada nasionalisme keagamaan, penanggulangan potensi radikalisme agama dapat berjalan baik.

Masih terkait dengan nasionalisme, tulisan Hanna Widayani, pada jurnal Manthiq Vol. 2, No. 2, November 2017, dengan judul "Ashabiyah Ibnu Khaldun dan Relevansinya dengan Nasionalisme Di Indonesia", menunjukkan hasil bahwa 'Ashâbiyah Ibnu Khaldun/solidaritas sosial dengan nasionalisme Indonesia sama- sama memiliki semangat untuk memperjuangkan cita-cita bangsa dan negara.

Berdasarkan pemaparan diatas, sangat jelas posisi penelitian ini. Sekalipun terdapat beberapa titik temu dengan penelitian sebelumnya, namun penelitian ini tetap terdapat perbedaan dan nilai keterbaharuan yang lanyak untuk dikaji.

\section{B. Konstruksi Pemikiran Keagamaan}

Penelitian ini menggunakan kerangka teori konstruksi sosial. Kajian konstruksi pemikiran keagamaan merupakan ranah kajian sosiologi pengetahuan. Sebuah cabang sosiologi yang mempelajari hubungan timbal balik antara pemikiran keagamaan dan masyarakat. Sosiologi pengetahuan berupaya untuk menghubungkan ide-ide dengan realitas masyarakat dan mengkaji setting historis tempat ide itu diproduksi dan diterima. ${ }^{10}$

Konstruksi pemikiran keagamaan adalah sebuah pernyatan keyakinan (claim) dan juga sebuah sudut pandang (point of view) bahwa kandungan dari kesadaran dan cara berhubungan dengan orang lain diajarkan oleh masyarakat dan kebudayaan. ${ }^{11}$ Dalam konstruksi sosial, individu membangun sendiri pengetahuan atas realitas yang dilihat berdasarkan struktur pengetahuan yang telah ada sebelumnya. Oleh sebab itu, realitas respons dan adaptasi masjid Agung tentang pemikiran keagamaan keagamaan tidak terbentuk dengan sendirinya, akan tetapi, realitas terbentuk karena adanya konstruksi sosial.

Berbicara teori konstruksi pemikiran keagamaan (social construction), tentu tidak dapat dilepaskan dari bangunan teoretik yang telah dikemukakan oleh

\footnotetext{
${ }^{10}$ Muhyar Fanani, Metode Studi Islam: Aplikasi Sosiologi Pengetahuan sebagai Cara Pandang (Yogyakarta: Pustaka Pelajar, 2010), 3.

${ }^{11}$ Charles R. Nugi, "Konstruksi Pemikiran Keagamaan dalam Realitas Sosial", dalam ASE- Vol. 7 No. 2 (2011):11.
} 
Peter L Berger dan Thomas Luckmann. ${ }^{12}$ Ada tiga momen di dalam teori Berger yaitu eksternalisasi, objektivasi dan internalisasi yang harus dipahami secara simultan. ${ }^{13}$ Dalam moment eksternalisasi, realitas sosial ditarik keluar diri individu. Di dalam momen ini, realitas sosial berupa proses adaptasi dengan teks-teks suci (seperti al-Qur'an dan al-Hadis) yang hal itu berada di luar diri manusia, sehingga dalam proses konstruksi pemikiran keagamaan melibatkan momen adaptasi diri antara teks dengan dunia sosio-kultural. Adaptasi tersebut dapat berupa bahasa, tindakan dan tradisi. Karena adaptasi merupakan proses penyesuaian berdasarkan penafsiran, maka sangat dimungkinkan terjadinya variasi-variasi adaptasi pada individu.

Pada moment objektivitasi, ada proses pembedaan dua realitas sosial yaitu realitas diri individu dan realitas sosial lain yang berada di luar individu. Sebagai momen interaksi dengan dunia sosio-kultural, maka di dalamnya melibatkan tarikmenarik antara agen seperti tokoh agama, masyarakat, politik, birokrasi dan sebagainya. Dalam proses konstruksi sosial, momen ini disebut sebagai interaksi sosial melalui pelembagaan dan legitimasi. Dalam pelembagaan dan legitimasi tersebut, agen bertugas untuk menarik dunia subjektivitasnya menjadi dunia objektif melalui interaksi sosial yang dibangun secara bersama. Agen-agen pelembagaan, seperti tokoh NU, Muhammadiyah, Tarbiyah, HTI, Salafi dan sebagainya.

Sedang terkait momen internalisasi, dunia realitas sosial yang objektif ditarik kembali ke dalam diri individu. Proses penarikan ke dalam diri individu ini melibatkan lembaga-lembaga di dalam masyarakat seperti lembaga agama, sosial. Melalui lembaga tersebut kemudian individu teridentifikasi di dalamnya. Tahap ini menghasilkan identifikasi individu sebagai bagian dari organisasi agama, sosial atau politik. Seperti sebutan Islam fundamentalis, liberal, tradisional, moderat dan

\footnotetext{
${ }^{12}$ Lihat: Peter L Berger and Thomas Luckmann, The Social construction of Reality A Treatise in the Sociology of Knowledge. Alih bahasa ke Indonesia oleh Hasan Basari dengan judul: Tafsir Sosial atas Kenyataan (Jakarta: LP3S, 1990).

${ }^{13}$ I. B. Putera Manuaba, "Memahami Teori Konstruksi Sosial", dalam Masyarakat, Kebudayaan dan Politik, Th. XXI. No. 3 (2008): 229.
} 
lainnya. ${ }^{14}$ Dimana setiap identivikasi tersebut memiliki ciri-ciri tertentu terkait sikap sosial, politik dan penafsiran teks agama.

Diantara ciri Islam fundamentalis menurut Ali Maschan Musa, dalam penfsiran teks agama misalkan, mereka cenderung tektual-skripturalis, normatif, tertutup, idialistik dan doktriner. Sedangkan Islam moderat memiliki kecenderungan kontekstualis, rasional terbuka, komprehensif dan realistik. ${ }^{15}$

\section{Nasionalisme}

Secara etimologis, term nasionalisme, natie dan national berasal dari bahasa Latin yakni nation yang berarti bangsa yang dipersatukan karena kelahiran. Sebuah paham kebangsaan yang mengandung makna kesadaran dan semangat cinta tanah air dan menjunjung tinggi nilai persatuan dan kesatuan. ${ }^{16}$

Nasionalisme direalisasikan dalam sebuah gerakan dalam kepentingan bangsa (nation) yang majemuk. Bangsa mempunyai pengertian totalitas yang tidak membedakan suku, ras, golongan dan agama. Terbentuk hubungan sosial yang harmonis dan sepadan atas dasar kekeluargaan. Kepentingan semua kelompok diinstitusionalisasikan dalam berbagai organisasi sosial, politik, ekonomi, dan keagamaan. Loyalitas tertinggi dari individu adalah untuk negara bangsa. Hal ini terjadi karena kesamaan keturunan, bahasa atau kebudayaan. Hal dalam terpenting dalam nasionalisme adalah adanya kemauan untuk bersatu. ${ }^{17}$

Menurut Sartono Kartodirdjo dalam Ali Maschan Moesa, ada lima prinsip yang saling terkait dalam nasionalisme yaitu (1) kesatuan (unity), (2) kemerdekaan (liberty) termasuk kebebasan mengemukakan pendapat, (3) persamaan (equality), (4) kepribadian (personality), (5) kualitas atau prestasi yang dibanggakan kepada bangsa lain (performance). ${ }^{18}$

\footnotetext{
14 Nur Syam. Islam Pesisir (Yogyakarta: LKIS, 2005), 43

15 Maschan Moesa, Nasionalisme Kiai: Konstruksi Sosial Berbasis Agama (Yokyakarta: LKIS Pelangi Aksara, 2007), 284-295.

16 Mifdal Zusron Alfaqi, "Memahami Indonesia Melalui Prespektif Nasionalisme, Politik Identitas, Serta Solidaritas", dalam Jurnal Pendidikan Pancasila dan Kewarganegaraan, Th. 28, Nomor 2 (2015): 112.

${ }^{17}$ Ali Maschan Moesa, Nasionalisme Kiai: Konstruksi pemikiran keagamaan Berbasis Agama, 28-29.

18 Ibid.
} 
Dengan demikian, konsep nasionalisme mengacu pada seperangkat gagasan yang membentuk kerangka konseptual tentang identitas nasional seperti konsep Pancasila, UUD 45, NKRI dan Benika Tunggal Ika bagi bangsa Indosesia. ${ }^{19}$

\section{Konstruksi Pemikiran Keagamaan Penceramah Tentang Nasionalisme di Masjid Agung Surakarta dan Masjid Baiturrohman Sukoharjo}

Konstruksi pemikiran keagamaan para penceramah kajian Islam di masjid Agung Surakarta dan Sukoharjo terkait nasionalisme adalah sebagai berikut ini:

\section{Pandangan Para Penceramah di Masjid Agung Surakarta Tentang Nilai-} Nilai Nasionalisme.

\section{a. Prof Nasruddin Baidan (PNS) ${ }^{20}$}

Terkait dengan nila-nilai nasionalisme, menurutnya ayat ke 13 surat alHujurat; "Hai manusia, sesungguhnya Kami menciptakan kamu dari seorang lakilaki dan seorang perempuan dan menjadikan kamu berbangsa-bangsa dan bersukusuku supaya kamu saling kenal-mengenal.

Beliau melihat sangat erat dengan makna nasionalisme. Terletak pada makna kata lita ârofu (saling kenal-mengenal). Adanya relasi yang baik saling mengenal, setiap orang merasa nyaman dengan orang lain, saling mencintai. Jadi seseorang dapat dikatakan memiliki nilai nasionalisem yang baik, jika dia sangat menghargai perbedaan dan menikmati perbedaan tersebut. Seseorang yang menyadari sebagai muslim yang benar, ia harus mau menerima sebuah realita keragaman. Mau tidak mau dia harus menjalin ikatan ukhuwah -persaudaraan-. Ukhuwah dengan makna secara umum. Baik ukhuwah îmâniyyah, ukhuwah wathaniyyah atau ukhuwah basyariah. Ukhuwah wathaniyyah berlandaskan kesamaan tanah air, kebersamaa, persaudaraan seprofesi dan ukhuwah-ukhuwah lainnya yang bersifat umum.

Masih menurut Nashruddin Baidan, nilai-nilai nasionalisme dapat diterima jika tidak bertentangan dengan aturan agama. Begitu pula cinta tanah air, menurutnya adalah sesuatu yang fitrah dan manusiawi. Sejarah mencatat bagaiman Rasulullah saw. mengungkapkan kecintaannya kepada kepada Makkah

19 Pimpinan MPR dan Badan Sosialisasi MPR RI, Empat Pilar MPR RI (Jakarta: Sekretariat Jendral MPR RI, 2018), 12-18.

${ }^{20}$ Wawancara dilaksanakan pada tanggal 30 Juli 2018. 
sebgai tanah kelahirannya. Sikap cinta tanah air selama tidak diidolakan dan tidak melanggar nilai agama adalah sah-sah aja.

Sedangkan asas musyawarah merupakan nilai yang bersesuaian dengan al- Qur'an Surat Al-Syura: 38. Nilai musyawah ini jika dilakukan secara jujur, trasnparan, konstitusion, maka akan memberikan kebaikan. Sayang yang ada sekarang ini hanya sekedar formalitas.

\section{b. Ustadz Hatta Syamsuddin (Aktivis Tarbiyah-PKS). ${ }^{21}$}

Menurutnya, nilai-nilai nasionalisme tidak ada pertentangan antara Islam dengan ideologi pancasila undang-undang dasar atau nilai- nilai nasionalisme lainnya. Yang jadi masalah adalah orang yang berusaha mempertentangkan hal tersebut. Karena orang semacam itu lupa akar sejarah perjuangan Indonesia. Dimana negara Indonesia ini semuanya berkalang tanah dan darah para ulama dan kaum muslimin. Untuk itu, umat Islam dituntut aktif untuk menjaga NKRI agar tetap menjadi tanah air bersama yang nyaman untuk menuaikan ibadah keyakinan masing-masing, aman untuk semua warga dan makmur bagi kehiduapan seluruh rakyat Indonesia.

Pancasila menurut Ustadz Hatta Syamsuddin, adalah sebuah kesepakan anak bangsa dan merupakan anugerah Allah subhanahu wa ta'âla yang diberikan kepada bangsa Indonesia. Sebagai sebuah nilai atau visi misi yang sepakati oleh para ulama dan komponen anak bangsa. Pancasila dapat dikatakan sebagai landasan bersama untuk mencapai sebuah cita-cita. Seperti halnya sebuah perusahaan atau keluarga pastilah memiliki kesepakatan- kesepakatan bersama, dengan kesepakatan tersebut menjadi sarana untuk mencapai cita-cita bersama. Jadi hal tersebut tidak dapat dikatakan bertentangan dengan Al-Qur'an atau Sunnah.

Berkaitan dengan cinta tanah air, menurut Hatta Syamsuddin bahwa kecintaan seorang muslim kepada tanah airnya adalah sesuatu yang inhern. Karena dalam prinsip dasar Islam, orang yang mempertahankan tanahnya, asetnya, atau hartanya adalah dinilai sebagai syahid. Logikanya orang yang mempertahankan

${ }^{21}$ Wawancara dilaksanakan pada 06 Agustus 2018. 
dan membela negaranya adalah sebuah perbutan yang jauh lebih patut untuk mendapatkan predikat syahid.

Mengenai toleransi dan keragaman atau puralitas, Hatta Syamsuddin berpendapat bahwa dalam sejarah Islam dikenal adanya piagam Madinah. Dimana dengan kesepakatan tersebut kaum muslimin dapat hidup berdampingan bersama komonitas laian seperti orang-orang yahudi dan lainnya. Itu artinya Rasulullah SAW. menerima adanya realita kehidupan yang beragama secara kepercayaan dan keimanan serta suku bangsa.

Adapun kasus pengusiran orang-orang Yahudi dari Madinah pada zaman Rasulullah adalah bukan kasus karena idiologi. Tetapi merekalah yang mengkhianati perjanjian yang telah disepakati bersama Rasulullah SAW.

Menurut Hatta Syamsuddin, ayat yang paling tepat berkaitan dengan toleransi adalah surah Mumtahanah: 8-9. Dua ayat ini menurutnya adalah ayat yang jelas menegaskan tetang hukum hubungan dengan non muslim. Selama Tidak melanggar kesepakatan, tidak melanggar perjanjian bersama. Semua taat dengan aturan yang disepakati. Maka tidak ada larangan untuk saling menghormati berbasis berbuat baik dalam koridor hukum yang berlaku.

Sedangkan pandangan terkait dengan penghormatan bendera merah putih dan lagu nasional, ustadz Hatta Syamsuddin melihat bahwa karena niatan dan gerakan bukan untuk ibadah. Maka hal tersebut tidak perlu diperdebatkan. Begitu pula lagu nasional adalah sebuah keniscayaan untuk menguatkan nasionalisme dan semua itu harus didasarkan dalam kebaikan bukan kejahatan. Dan tentu sikap nasionalisme harus diukur dengan al-Qur'an dan Sunnah. Bukan nasionalisme yang membabi buta. Selama nilai-nilai nasionalime tersebut tidak bertentangan dengan ajaran Islam maka tidak perlu dipertentangkan.

Sekali lagi Hatta berpesan bahwa nasionalisme adalah sebuah nilai bukan sekedar alat. Jika sebagai alat ia akan dijadikan alat kepentingan kelompok tertentu untuk menilai atau bahkan mengancurkan kelopok lain yang berseberangan. Jadi nasionalisme adalah nilai yang harus diperjuangkan dan dijalankan sesuai kemampuan masing-masing. Dan bukan sebaliknya mencadi alat untuk menuduh dan memojokkan kelompok lain dengan tuduhan tidak nasionalisme. 


\section{c- Ustadz Faishal (Aktivis HTI) ${ }^{22}$}

Pandangan ustadz Faishal tentang Pancasila ia melihat bahwa Pertama, ketika melaksanakan ajaran Islam dengan benar maka sudah dapat dipastikan dia seorang pancasilais, bukan sebaliknya. Karena dalam Pancasila aturan yang ada adalah masih sangat umum sekali atau mujmal. Misalkan ketika kita tanya apa hukumnya orang yang mencuri dalam Pancasila atau apa hukumnya riba dalam Pancasila? Tentu jawabnnya masih sangat umum sekali. Tidak ada penjelasan terkait tentang masalah tersebut dalam pancasila.

Kedua, bahwa jangan sampai pula ada orang mengaku Pancasilais, tetapi perilakunya jauh daripada nilai-nilai Pancasila. Dan jangan pula sampai slogan bela Pancasila itu hanya untuk memberangus kelompok-kelompok lain yang tidak sepaham dengannya.

Terkait dengan persoalan khilâfah dan NKRI ustadz Faishol berpendapat bahwa: khilâfah ketika tegak bukan berarti NKRI harus hilang. Sebab ketika Islam diturunkan dan diamalkan maka apapun menjadi kuat. Baik secara personal muslim maupun negara. Dengan kata lain, ketika Islam itu tegak di Indonesia, maka Indonesia akan berpotensi menjadi negara kuat semakin terbuka lebar. Khilâfah ketika tegak tidak melenyapkan NKRI dan tidak melebur batas-batas toretorial. Justru menurut Faishal, dengan khilâfah potensi-potensi yang dimiliki kaum muslimin akan terkumpul menjadi sebuah kekuatan. ${ }^{23}$ Karena sebenarnya yang dihadapi orang Islam sekarang ini adalah munculnya ide-ide yang memiliki kekuasaan tanpa batas. Seperti paham-paham imperalisme, yang dianut oleh negara-negara besar saat ini.

Adapun pandangan ustadz Faishal terkait cinta tanah air, menurutnya mencintai tanah air adalah sesuatu yang fitrah karena tempat lahir tempat dimana seseorang hidup, maka kecintaan tersebut tidak dilarang. Tentu cinta dalam karedor syariah. Dengan kata lain, sikap nasionalisme seseorang itu tidak boleh ditempatkan melebihi Islam. Jadi tidak boleh atas nama satu nasionalisme, lalu

\footnotetext{
22 Wawancara dilaksanakan pada tanggal 05 Agustus 2018.

23 Sebagaimana disebutkan dalam buku pegangan HTI "Nidhomul Islam" karya Taqiyyuddin anNabhani, (Mansyuraat Hizbut Tahrir, 2001), 103. Disebutkan pada maddah ke 52 terkait pembagian negara, bahwa negara dibagi menjadi beberapa bagian wilayah. Bisa jadi yang dimaksud wilayah ini adalah negara-negara bagin termasuk NKRI sebagai wilayah di Indonesia?.
} 
dibela mati-matian padahal dia salah. Maka nasionalisme semacam ini harus diluruskan.

Terkait dengan keberagaman agama atau pluralitas, menurut ustadz Faishol, harus dibedakan antara pluralitas dan pluralisme. Pluralitas menurutnya adalah sesuatu yang manusiawi artinya manusia itu berbeda-beda bermacam-macam. Sedangkan pluralisme Ini adalah sebuah paham yang menganggap seluruh agama adalah benar. Pemahaman semacam ini ustadz Faisal tidak setuju karena mengakui semua agama sama benarnya. Pemahaman tersebut bertenatangan dengan Islam. Karena jelas dalam al-Qur'an dikatakan innaddîna I'ndallâhil Islâm “Agama yang benar disisi Allah adalah Islam (Ali Imran: 19).

\section{E. Pandangan Para Penceramah agama di Masjid Agung Sukoharjo Tentang Nilai-Nilai Nasionalisme.}

Berikut ini hasil wawancara para penceramah agama di Masjid Agung Sukoharjo tentang nilai-nilai Nasionalisme:

\section{Drs. H. Lasimin, M.Pd (Aktifis NU Sukoharjo). ${ }^{24}$}

Menurutnya, NU sudah sejak lama mengedepankan Islam yang ramah dan moderat. Nahdalatul Ulama (NU) mengembangkan Islam yang ramah dan moderat (Tawâsuț), Tawâzun (seimbang) dan Al-I'tidâl (tegak lurus) dan Tasâmun (toleransi). Sikap nasionalime merupakan unsur penting dalam membangun bangsa dan agama.

Rasulullah SAW. merupakan sosok yang sangat menjunjung tinggi nilai nasionalisme. Karena itulah kecintaan Rasulullah SAW.terhadap tanah kelahirannya sangat besar. Rasulullah saat berada di Madinah pernah bersabda "Seandainya aku tidak diusir maka aku tidak akan pindah dari Mekkah" (HR. atTirmidzi dan Ibnu Mâjah). Sebagai bentuk keteladaan kepada Rasulullah SAW. adalah dengan membangun masyarakat yang baik.

${ }^{24}$ Wawancara dilaksanakan pada 01 Juni 2018 dikediamannya. 


\section{Ustad Abdurrahman (Aktifis Salafi) ${ }^{25}$}

Berkaitan dengan cinta tanah air menurut menurutnya tidak ada hadis nabawi yang menyebutkan bahwa hubbul wațon adalah sebagian dari iman. Namun seseorang itu secara tabiat mencintai tanah airnya. Mencintai tanah air itu tidak dilarang dalam Islam, hal ini dapatlah diibaratkan seperti misalnya mencintai istri dan rumah, mencintai sesama manusia, mencintai suku-suku bangsa tertentu dan sebagainya.Istilahnya dalam Islam itu tidak melarang mencintai tanah airnya.

Meski demikian, kita tidak boleh a'sobiyyah (fanatik buta) karena pembelaan terhadap keturunan. a'śbiyyah itu terlarang dalam Islam. Tetapi seandainya ada orang ingin mehancurkan Indonesia, tentu saya akan membela Indonesia sebagi bangsa dan tanah kelahiran. Mencintai tanah kelahiran adalah tabiat setiap manusia. Nabi Muhammad SAW sendiri tetap mencintai kota Makkah dan mencintai kota Medinah. Inilah do`a nabi Muhammad SAW. "Allâhumma habbib ilainâ al-Madînah ka hubbinâ Makkata aw asyadda "artinya Ya Allah cintakanlah aku pada Madinah seperti halnya aku mencintai Makkah, atau bahkan lebih (HR. Muslim). Nabi mencintai kedua kota tersebut, sehingga keduanya disebut dengan Haromain (dua kota yang yang dimuliakan).

Terkaitan dengan lambang negara dan Ideologi Pancasila menurut ustadz Abdurrohman, bahwa setiap sistem pemerintahan pasti mempunyai tanda-tanda (simbol negara) misalnya bendera merah putih, Garuda Pancasila, lagu Indonesia Raya sebagai lambang negara Indonesia. Lambang-lambang itu harus dihormati, tetapi tidak berlebihan. Karena atas Rahmat Allah dan dilandasi oleh adanya keinginan yang luhur dari seluruh bangsa Indonesia, bangsa ini merdeka.

Sedang terkait demokrasi, menurut ustadz Abdurrohman demokrasi itu berasal dari dunia Barat. Tidak ada dalam Islam. Islam hanya mengenal musyawarah yang bertujuan mengambil kesepakatan tentang maslahat dari madhorot. Tetapi karena realitas negara Indonesia saat ini menganut system negara demokrasi, maka tetap harus mentaati pemerintah (sami'nâ wa'ato'nâ). Menurut Abdurrohman, tugas kita adalah mendoakan pemerintah dan melakukan da'wah tanpa kekerasan.

\footnotetext{
25 Wawancara dilaksanakan pada 31 Juli 2018 dikediamannya.
} 
Sikap ustadz Abdurrohman semacam itu, tidaklah aneh. Karena sikap kelompok salafi terhadap pemerintah adalah wajib mentaati selama tidak dalam kemaksiatan. ${ }^{26}$ Bahkan sebagian mereka mengharamkan demontrasi. ${ }^{27}$ Yang boleh dilakukan adalah menasehari pemerintah dengan cara-cara yang baik.

Berkaitan dengan persoalan persatuan dan kesatuan bangsa, menurut Abdurrohman, bahwa keumuman ayat al-Qur'an menjelaskan tentang keharusan untuk bersatu walaupun adanya perbedaan. Dalam Piagam Madinah Nabi SAW pernah melakukan perjanjian antar suku tidak saling menyerang dan saling menjaga. Maka diterapkan, "lakum dinukum waliyadin" "bagimu agamamu" (Qs. alKafirun: 6) dan Surat al-Baqoroh: 256, "Tidak ada paksaan untuk (memasuki) agama (Islam). Jadi bermuamalah dengan orang kafir terkait urusan duniawi tidak dilarang.

\section{F. Wawasan Nasionalisme Para Penceramah Kajian Islam Di Masjid Agung Surakarta Dan Masjid Agung Baiturrohman Sukoharjo.}

Berdasarkan hasil pemaparan di atas dapat disimpulkan bahwa wawasan nasionalisme para pencermaah pada kajian keislaman di masjid Agung Surakarta Dan masjid Agung Baiturrohman Sukoharjo, telah mencakup unsur-unsur nasionalime berikut ini:

\section{Pancasila}

Para penceramah kajian Islam baik di Masjid Agung Surakarta maupun masjid Agung Baiturrohman Sukoharjo, secara umum menerima Pancasila sebagai dasar negara. Mereka menganggap bahwa Pancasila tidak bertentangan dengan ajaran Islam. Pancasila sebagai sebuah kesepakatan anak bangsa. Bahkan dapat dikatakan bahwa Pancasila merupakan anugerah Allah SWT. yang diberikan kepada bangsa Indonesia sebagai sebuah nilai atau visi misi yang telah disepakati oleh para ulama sebagai komponen anak Bangsa.

Pancasila dapat dikatakan sebagai landasan bersama untuk mencapai sebuah cita-cita. Seperti halnya sebuah perusahaan pastilah memiliki kesepakatan-

\footnotetext{
${ }^{26}$ Muhammadin, “Manhaj Salafiyyah”, dalam Jurnal Ilmu Agama, Th. XIV/ No. 2 (2013): 153-154.

27 Lihat misalkan salah situs mereka: https://almanhaj.or.id/2141-demonstrasi-solusi-ataupolusi.html, diakses pada 06 Nopember 2018.
} 
kesepakatan bersama, dengan kesepakatan tersebut menjadi sarana untuk mencapai cita-cita bersama. Begitu pula sebuah negara Indonesia yang memiliki dasar Pancasila, Undang-Undang Dasar 1945 sebagai sebuah kesepakatan bersama untuk mencapai tujuan sebagai sebuah negara dan bangsa. Hal ini yang disebut dengan istilah (kalimah al-sawâ') asas yang mengandung nilai-nilai atau prinsip yang bisa menjadi titik temu bagi seluruh komponen bangsa. ${ }^{28}$ Jadi hal tersebut tidak dapat dikatakan bertentangan dengan al-Qur'an atau Sunnah. Seorang muslim yang benar pasti pancasilais, bukan sebaliknya.

\section{Cinta Tanah Air dan NKRI}

Para penceramah kajian Islam di masjid Agung Surakarta maupun masjid Agung Baiturrohman Sukoharjo sepakat bahwa cinta tanah air adalah sesuatu yang fitrah dan manusiawi. Kecintaan seorang muslim kepada tanah airnya adalah sesuatu yang inhern karena dalam prinsip dasar Islam menjadikan orang yang mempertahankan tanahnya, atau hartanya adalah dinilai sebagai syahid.

Sikap cinta tanah air selama tidak membabi buta dan tidak melanggar nilai agama, maka dapat dibenarkan. Selama cinta tanah air itu berada di jalur yang benar menurut syariat Islam, maka hal tersebut diperbolehkan. Seperti membela tanah air dari rongrongan asing dan asong.

Nasionalisme juga jangan sampai sekedar slogan dan ucapan tetapi harus dibuktikan dalam perilaku. Seperti misalkan menasionalismekan Freeport dan lain-lain. Jika ada orang yang meragukan muslim tentang kecintaan kepada tanah air adalah berarti termasuk orang yang ahistoris. Kalau ada orang yang menuduh bahwa para ulama merongrong NKRI atau umat Islam adalah anti NKRI adalah tuduhan yang menyakitkan dan merupakan fitnah keji kepada umat Islam.

Sedangkan menurut penceramah HTI sekalipun menegaskan tentang cinta tanah air dan NKRI, tetapi tetap berharap sistem NKRI dibawah sistem Khilafah. Karena HTI menyakini bahwa sistem Khilafah adalah harga mati yang harus diwujudkan dalam tatanan kehidupan. ${ }^{29}$

\footnotetext{
${ }^{28}$ MK Ridwan, Penafsiran Pancasila dalam Perspektif Islam:Peta Konsep Integrasi, dalam Dialogia, Vol. 15, No. 2, (2017): 209.

29 Asep Zaenal Ausop, "Demokrasi dan Musyawarah dalam Pandangan Darul Arqam, Nii, Dan Hizbut Tahrir Indonesia”, dalam Jurnal Sosioteknologi, Edisi 17 Th 8, (2009): 612.
} 


\section{Toleransi dan Pluralitas}

Semua penceramah kajian Islam di masjid Agung Surakarta dan masjid Agung Baiturrohman Sukoharjo melihat bahwa toleransi dan pluralitas adalah sebuah keniscayaan. Dan Islam sejak abad ke-7 melalui al-Qur'an telah menegaskan tentang hak kebebasan berkenyakinan bagi setiap manusia. ${ }^{30}$ Bahkan salah satu hal yang sangat prinsip dalam ajaran agama Islam. Sehingga keberadaanya tidak mungkin untuk dianulir dalam kondisi apapun. ${ }^{31}$

Kaidah hubungan antara muslim dan non muslim sangat jelas aturannya dalam Islam. Sebagaimana telah dijelaskan dalam Q.S al-Mumtahanah 8-9. Intinya, selama tidak melanggar kesepakatan, tidak melanggar perjanjian bersama. Semua taat dengan aturan yang disepakati. Maka tidak ada larangan untuk saling menghormati, berbasis berbuat baik dalam koridor hukum yang berlaku.

Namun menurut para penceramah, perlu dibedakan antara pluralitas dan pluralisme. Pluralitas adalah adalah sebuah realita kehidupan. Sedangkan pluralisme adalah sebuah paham yang menganggap seluruh agama adalah benar. Pemahaman ini tidak dapat diterima oleh para penceramah karena bertenatangan dengan ajaran Islam. Yaitu "innaddina indallahil Islam", Sesunguhnya agama yang diterima oleh Allah hanyalah Islam (Ali Imran: 19).

Toleransi antar umat beragama yang benar menurut Islam adalah sikap saling membiarkan dan menjaga suasana kondusif bagi antar umat agama lain untuk melaksanakan ibadah kepercayaannya tanpa ada gangguan apapun. ${ }^{32}$ Dan sebenarnya terkait toleransi, kita sebagai bangsa Indonesia telah mampu memberikan contoh terbaik bagi dunia. Terbukti negara mengakui agama-agama yang hidup di bumi pertiwi. Apakah pengakuan semacam ini dapat ditemukan di negara-negara lain yang menggembar-ngemborkan toleransi?

\section{Demokrasi dan Syura}

\footnotetext{
30 Moh. Abdul Kholiq Hasan, "Ayat-Ayat Kebebasan Beragama dalam Perspektif Nasakh: Kajian Terhadap Penafsiran Ibn Kathîr Dan Rashîd Ridâ”, dalam Jurnal Mutawatir, Vol. 6, No. 02, (2016): 284

31 Moh. Abdul Kholiq Hasan, Freedom Of Religion In Rashid Rida's Perspective, Advances in Social Science, Education and Humanities Research (ASSEHR), volume 137. International Conference on Qur'an and Hadith Studies (ICQHS 2017), 59.

32 Suryan A. Jamrah, "Toleransi Antarumat Beragama: Perspektif Islam", dalam Jurnal Ushuluddin, Vol. 23 No.2, (2015):186
} 
Para penceramah kajian Islam di Masjid Agung Surakarta dan Masjid Agung Baiturrohman Sukoharjo sepakat bahwa sistem demokrasi berbeda dengan syura atau musyawarah. Asas Musyawah merupakan nilai yang bersesuaian dengan ayat al-Qur'an surah al-Syura: 38. Nilai-nilai musyawah ini jika dilakukan secara jujur, trasnparan, konstitusion, maka nilai musyawarah dapat dibenarkan.

Sistem demokrasi menurut para penceramah di masjid Agung Surakarta dan masjid Agung Baiturrohman Sukoharjo, bukanlah produk asli Indonesia. Lalu diadopsi ke Indonesia, maka lahirlah apa yang dikenal dengan demokrasi Pancasila. Karenanya ada sebagian umat Islam seperti penceramah yang berafiliansi HTI secara tegas menolak sistem demokrasi, diangapnya sebagai sistem kafir dan najis. Karena demokrasi ini menjadikan kedaulatan ditangan rakyat. Hal ini menurutnya bertentangan dengan Islam. 33

Sekalipun HTI beranggapan bahwa demokrasi adalah sistem kafir dan najis, namun realitanya mereka memanfaatkan sistem tersebut untuk mengembangkan sayap politiknya. Dan justru gerakan mereka berkembang di negara-negara yang menganut dan menerapakan sistem demokrasi. ${ }^{34}$ Ini adalah salah satu ketidak konsistenan mereka.

Demokrasi menurut para penceramah dari HTI berbeda dengan Syura atau musyawarah pada umumnya. Dalam syura terdapat batas-batasnya jika hal tersebut terkait dengan syariat dan telah dijelaskan hukumnya lewat teks-teks agama, maka tidak lagi berlaku syura. Semua harus tunduk kepada ketantuan Allah dan Rasul. Berbeda dengan demokarasi, menjadikan keputusan semua tunduk atas kemauan rakyat. 35 Termasuk kritik terhadap demokrasi adalah kedudukan suara seseorang dalam pemilihan sama antara suara kyai (ulama) dengan rakyat jelata.

Pendapat diatas dianggap pendapat yang lemah menurut penceramah aktifis PKS. Karena menurutnya, mayoritas ulama kontemporer dunia sekarang ini membolehkan penggunaan demokrasi sebagai salah satu sarana untuk perjuang kepentingan umat. Disamping itu, perintah dakwah tidak dibatasi oleh suatu

\footnotetext{
33 Karman, "Delegitimasi Demokrasi oleh Organisasi Muslim Revivalis: Pendekatan Analisis Wacana", dalam Jurnal Penelitian Komunikasi dan Opini Publik, Vol. 19 No. 2 (2015): 133

34 Agung Wijaksono, Ahmad Jamaan "Gerakan Politik Islam Hizbut Tahrir di Indonesia Pada Era Pasca Reformasi”, dalam Jornal Online Mahasiswa FISIP, Vol. 1 No. 2 (2014): 6

35 Asep Zaenal Ausop, "Demokrasi dan Musyawarah dalam Pandangan Darul Arqam, Nii, Dan Hizbut Tahrir Indonesi”, 614.
} 
tempat atau kondisi. Termasuk dakwah didalam parlemen ada haknya untuk didakwahi. Untuk itu Tarbiyah-PKS termasuk partai yang menerima sistem demokrasi dan ikut dalam pesta demokasi. ${ }^{36}$

Diantara keberatan lain HTI adalah antara teori demokrasi dan realita lapangan tidak nyambung. Seperti yang terjadi Aljazair dan Mesir. Dimana kaum muslimin menang dalam pemilihan dengan sistem demokrasi. Namun ketika menginginkan diterapkannya syariat, orang-orang yang mengakampanyekan demokrasi selama ini, justru merekalah yang menolak keras hasil pemilihan tersebut dan melengserkannya dengan cara-cara yang tidak demokratis.

\section{Hormat Bendera dan Luga Nasionalisme}

Hormat bendera tidak bertentangan dengan Islam. Karena niat dan gerakannya bukan untuk ibadah. Oleh karenanya itu, HTI pun memasang bendera merah putih ketika tanggal 17 Agustus. Manurutnya hanya sekedar administrasi. Begitu pula lagu nasional adalah sebuah keniscayaan untuk menguatkan nasionalisme dan semua itu harus didasarkan dalam kebaikan bukan kejahatan.

Dasar dalam hal ini adalah hadis Rasulullah SAW "Tidak ada keataatan kepada makhluk, jika menjadikan kemaksiatan kepada Allah". Untuk itu HTI tidak sependapat bahwa melantunkan lagu nasionalisme itu sebagai bentuk kesyirikan.

Upacara bendara dan melagukan lagu-lagu kebangsaan tidak lain adalah untuk menanamkan nilai-nilai nasionalisme. ${ }^{37}$ Walaupun demikian, sikap nasionalisme ini harus diukur dengan Syariah. Bukan nasionalisme yang membabi buta. Selama tidak bertentangan dengan ajaran Islam maka tidak perlu dipertentangkan. Dan jangan sampai nasionalisme hanya sekedar alat kepentingan untuk kelompok tertentu untuk menilai kelompok lain.

\section{Kesimpulan}

Berdasarkan pembahasan diatas, hasil penelitian dapat disimpulkan sebagai berikut:

\footnotetext{
${ }^{36}$ Gonda Yumitro, "Partai Islam dalam Dinamika Demokrasi di Indonesia", dalam Jurnal Ilmu Sosial dan Ilmu Politik, Vol. 17, No. 1 (2013): 44

37 Chairul Anwar, "Internalisasi Semangat Nasionalisme Melalui Pendekatan Habituasi (Perspektif Filsafat Pendidikan)", dalam ANALISIS: Jurnal Studi Keislaman, Vol.14, No1 (2014): 170
} 
Konstruksi pemikiran keagamaan tentang wawasan nasionalisme pada penceramah kajian Islam di masjid Agung Surakarta dan Kabupaten Sukoharjo dapat dibagi menjadi dua tipe. Pertama: Islamis tekstual yaitu pemikiran nasionalis yang selalu menjadikan teks-teks agama sebagai pijakan satu-satunya. Hal ini terlihat dari pemahaman penceramah HTI dan Salafi. Kedua, Islamis kontektual, yaitu pemikiran nasionalis yang tidak menjadikan teks-teks agama sebagai pijakan satu-satunya, tetapi juga melihat rialita dan maqâsid syarî́ah. Tipe semacam ini dapat terlihat pada penceramah PKS dan NU.

Wawasan nasionalisme yang dimiliki para pencermah pada kajian Islam di masjid Agung Kota Surakarta dan Kabupaten Sukoharjo, telah mencakup lima pokok nilai-nilai nasionalisme. Yaitu; Pancasila sebagai ideologi negara, cinta tanah air dan NKRI, toleransi dan keragaman, demokrasi dan musyawarah, hormat bendera merah putih serta lagu kebangsaan. Secara umum para penceramah menerima dan mendukung kelima prinsip tersebut. Kecuali terkait dengan demokrasi yang menurut pencermah HTI dan salafi bertentangan dengan Islam. HTI menerima konsep NKRI, tetapi dibawah naungan sistem khilafâh.

\section{DAFTAR PUSTAKA}

Alfaqi, Mifdal Zusron. "Memahami Indonesia Melalui Prespektif Nasionalisme, Politik Identitas, Serta Solidaritas", Jurnal Pendidikan Pancasila dan Kewarganegaraan, Th. 28, No 2 (2015):111-116.

Anwar, Chairul. "Internalisasi Semangat Nasionalisme Melalui Pendekatan Habituasi (Perspektif Filsafat Pendidikan)" dalam ANALISIS: Jurnal Studi Keislaman, Vol.14, No1 (2014): 159-172.

Ausop, Asep Zaenal, "Demokrasi dan Musyawarah dalam Pandangan Darul Arqam, Nii, Dan Hizbut Tahrir Indonesia", dalam Jurnal Sosioteknologi, Edisi 17 Th 8, (2009):601-620.

Fanani, Muhyar. Metode Studi Islam: Aplikasi Sosiologi Pengetahuan sebagai Cara Pandang, Yogyakarta: Pustaka Pelajar, 2010.

Hasan, Moh. Abdul Kholiq. "Ayat-Ayat Kebebasan Beragama dalam Perspektif Nasakh: Kajian Terhadap Penafsiran Ibn Kathîr Dan Rashîd Ridâ", Jurnal Mutawatir, Vol 06, No. 02 (2016): 284-313.

Hasan, Moh. Abdul Kholiq. Metode salafush shalih dalam berinteraksi dengan AlQuran", Jurnal Al-'ARAF, Vol. XII, No. 2 (2015): 51-67. 
Hasan, Moh. Abdul Kholiq. "Freedom of Religion In Rashid Rida's Perspective", Advances in Social Science, Education and Humanities Research (ASSEHR), volume 137. International Conference on Qur'an and Hadith Studies ICQHS 2017. 56-59.

Hasan, Moh. Abdul Kholiq. Penafsiran Alquran dan ikhtilaf Ulama (Kaidah dan Etika Memahami Perbedaan Penafsiran)", El-Hayah-Jurnal Ilmu-Ilmu Keislaman, Vol. 1 No. 1 (2012): 13-24.

Jamrah, Suryan A. “Toleransi Antarumat Beragama: Perspektif Islam”, Jurnal Ushuluddin, Vol. 23 No.2, (2015):185-200.

Karman, "Delegitimasi Demokrasi oleh Organisasi Muslim Revivalis: Pendekatan Analisis Wacana", dalam Jurnal Penelitian Komunikasi dan Opini Publik, Vol. 19 No. 2 Agustus 2015: 127-140.

Manuaba, I. B. Putera. "Memahami Teori Konstruksi Sosial", Masyarakat, Kebudayaan dan Politik, Th. XXI. no. 3, (2008): 221-230.

Moesa, Ali Maschan. Nasionalisme Kiai: Konstruksi pemikiran keagamaan Berbasis Agama. Yogyakarta: LKIS, 2007.

Muhammadin, "Manhaj Salafiyyah", dalam Jurnal Ilmu Agama, Th. XIV/ No. 2 (2013): 147-161.

Nugi, Charles. R. "Konstruksi Pemikiran Keagamaan dalam Realitas Sosial”, ASE-7, No 2 (2001): 11.

Pimpinan MPR dan Badan Sosialisasi MPR RI, Empat Pilar MPR RI, Jakarta: Sekretariat Jendral MPR RI, 2018.

Reflita, "Kontroversi Hermeneutika Sebagai Manhaj Tafsir (Menimbang Penggunaan Hermeneutika dalam Penafsiran al-Qur'an)", Jurnal Ushuluddin, Vol. 24 No.2, (2016): 135-149.

Ridwan, MK, Penafsiran Pancasila dalam Perspektif Islam:Peta Konsep Integrasi, dalam Dialogia, Vol. 15, No. 2, (2017): 203-224.

Sutopo, H.B. Metode Penelitian Kualitatif, Surakarta: Universitas Sebelas Maret, 2006.

Syam, Nur. Islam Pesisir, Yogyakarta: LKIS, 2005.

Tim Penulis, Sejarah Masjid Agung Surakarta, Yokyakarta: Absolute Media, 2014.

Water, Malcoln. Modern Sociological Theory, London: Saga Publications, 1994.

Wawancara dengan Abdurrahman, aktifis Salafi, dilaksanakan pada 31 Juli 2018 dikediamannya.

Wawancara dengan Faishol, aktifis HTI, dilaksanakan pada tanggal 05 Agustus 2018.

Wawancara dengan Hatta Syamsuddin, aktivis PKS, dilaksanakan pada 06 Agustus 2018.

Wawancara dengan Lasimin, aktifis NU dilaksanakan pada 01 Juni 2018 dikediamannya. 
Wawancara dengan Nashruddin Baidan, Dosen, PNS, dilaksanakan pada tanggal 30 Juli 2018.

Wawancara dengan Yazid Anwari, ketua umum pengurus masjid Agung Sukoharjo, pada tanggal 9 Juli 2018.

Wijaksono, Agung. "Gerakan Politik Islam Hizbut Tahrir di Indonesia Pada Era Pasca Reformasi”, dalam Jornal Online Mahasiswa FISIP, Vol. 1 No. 2 (2014):1-6

Yumitro, Gonda, "Partai Islam dalam Dinamika Demokrasi di Indonesia", dalam Jurnal Ilmu Sosial dan Ilmu Politik, Vol. 17, No. 1 (2013): 35-50 